ISSN: 1907-9931 (print), 2476-9991 (online)

\title{
PROFIL GC-MS DARI EKSTRAK DAUN RHIZOPHORA APICULATA DARI PESISIR TELUK TOMINI, SULAWESI TENGAH DENGAN AKTIVITAS ANTIBAKTERI DAN ANTIOKSIDAN

\author{
GC-MS PROFILE OF RHIZOPHORA APICULATA LEAF EXTRACT FROM THE COAST OF \\ TOMINI BAY, CENTRAL SULAWESI WITH ANTIBACTERIAL AND ANTIOXIDANT ACTIVITY
}

\author{
Didit Kustantio Dewanto ${ }^{1 *}$, Roni Hermawan ${ }^{1}$, Muliadin ${ }^{1}$, Putut Har Riyadi ${ }^{2}$, Siti Aisiah ${ }^{3}$, dan \\ Wendy Alexander Tanod ${ }^{4^{*}}$ \\ ${ }^{1}$ Sekolah Tinggi Perikanan dan Kelautan - STPL Palu, Palu Jalan Soekarno Hatta KM. 6 Kampus \\ Madani, Palu, 94118 Sulawesi Tengah \\ ${ }^{2}$ Departemen Teknologi Hasil Perikanan, Fakultas Perikanan dan IImu Kelautan Universitas \\ Diponegoro, Jalan Prof. Soedarto, SH Tembalang, Semarang, 50275 Jawa Tengah \\ ${ }^{3}$ Program Studi Budidaya Perairan, Fakultas Perikanan dan Kelautan, Universitas Lambung \\ Mangkurat, Jalan Ahmad Yani KM 36, SH Banjarbaru, 70714 Kalimantan Selatan \\ ${ }^{4}$ Jurusan Perikanan dan Kebaharian, Politeknik Negeri Nusa Utara Jalan Kesehatan No.1, Sawang \\ Bendar, Tahuna, 95812, Sulawesi Utara
}

*Corresponding author email: wendytanod@gmail.com

Submitted: 30 October 2020 / Revised: 20 March 2021 / Accepted: 28 April 2021

http://doi.org/10.21107/jk.v14i1.8904

\begin{abstract}
Mangroves are plants with good tolerance to salinity changes, developing a chemical defense system with pharmacological value. This study aimed to obtain a GC-MS profiles of Rhizophora apiculata mangrove leaves extract, which could scavenge DPPH radicals and inhibit the growth of Listeria monocytogenes, Salmonella typhimurium, and Pseudomonas aeruginosa. The research included sampling, extraction (maceration with MeOH:DCM), identification of chemical profiles using GC-MS spectra analysis, assaying for antibacterial activity (well diffusion method), and antioxidants (DPPH radical scavenging). Mangrove leaves sampling was carried out on Laemanta, Parigi Moutong, Central Sulawesi. Based on the leaves' characteristics and tips, the types of roots, fruits, and flowers, the mangrove leave samples were identified as $R$. apiculata. The GC-MS profiles of R. apiculata leaves extract was dominated by mome inositol (75.6\%). The antibacterial assay showed at a concentration of $100 \mathrm{mg} / \mathrm{mL}$ of $R$. apiculata leaves extract showed weak to strong antibacterial activity, with the inhibition zone diameter of $P$. aeruginosa $(1.22 \pm 0.39 \mathrm{~mm})$, S. typhimurium $(3.00 \pm$ $1.20 \mathrm{~mm})$, and $L$. monocytogenes $(17.22 \pm 1.26 \mathrm{~mm})$. The leaves extract of $R$. apiculata showed antioxidant activity, with an $1 C_{50}$ value of $96.68 \pm 0.68 \mu \mathrm{g} / \mathrm{mL}$. Based on the results, the mangrove leaves of $R$. apiculata extracts showed potential antibacterial and antioxidant activity. This study indicated that $R$. apiculata from Central Sulawesi were potential mangroves to discover and develop antibacterial and antioxidant agents.
\end{abstract}

Keywords: GC-MS, Listeria monocytogenes, Parigi Moutong, Pseudomonas aeruginosa, Salmonella typhimurium.

\begin{abstract}
ABSTRAK
Mangrove merupakan tumbuhan dengan toleransi baik terhadap perubahan salinitas, sehingga mengembangkan suatu sistem pertahanan kimia yang bernilai farmakologis. Penelitian ini bertujuan mendapatkan profil senyawa dengan GC-MS dari ekstrak daun mangrove Rhizophora apiculata yang dapat menangkap radikal DPPH dan menghambat pertumbuhan Listeria monocytogenes, Salmonella typhimurium, dan Pseudomonas aeruginosa. Penelitian meliputi pengambilan sampel, ekstraksi daun mangrove (maserasi dengan MeOH:DCM), identifikasi profil senyawa dengan analisis spektra GCMS, pengujian aktivitas antibakteri (metode difusi sumur) dan antioksidan (penangkapan radikal $D P P H)$. Pengambilan sampel daun mangrove dilakukan di pesisir Desa Laemanta, Kabupaten Parigi Moutong, Sulawesi Tengah. Berdasarkan karakteristik bentuk dan ujung daun, jenis akar, buah, dan
\end{abstract}


bunga, sampel daun mangrove terindentifikasi Rhizophora apiculata. Profil GC-MS dari ekstrak daun R. apiculata didominasi oleh senyawa mome inositol (75,6\%). Hasil pengujian antibakteri pada konsentrasi $100 \mathrm{mg} / \mathrm{mL}$ ekstrak daun $R$. apiculata menunjukkan aktivitas antibakteri yang lemah sampai kuat, dengan diameter zona hambat pada $P$. aeruginosa $(1,22 \pm 0,39 \mathrm{~mm})$, dan $S$. typhimurium $(3,00 \pm 1,20 \mathrm{~mm})$, L. monocytogenes $(17,22 \pm 1,26 \mathrm{~mm})$. Ekstrak daun $R$. apiculata menunjukkan aktivitas antioksidan dengan nilai $1 C_{50}$ sebesar $96.68 \pm 0.68 \mu \mathrm{g} / \mathrm{mL}$. Berdasarkan hasil pengujian ekstrak daun mangrove $R$. apiculata menunjukkan aktivitas antibakteri dan antioksidan. Penelitian ini mengindikasikan bahwa $R$. apiculata asal Sulawesi Tengah menjadi mangrove yang potensial dijadikan sebagai agen antibakteri dan antioksidan.

Kata Kunci: GC-MS, Listeria monocytogenes, Parigi Moutong, Pseudomonas aeruginosa, Salmonella typhimurium.

\section{PENDAHULUAN}

Mangrove merupakan tumbuhan yang tumbuh di hutan tropis dan banyak dimanfaatkan sebagai sumber kayu, bahan makanan, dan pakan ternak (Bandaranayake, 2002). Tumbuhan mangrove memiliki banyak manfaat bagi kehidupan manusia, mulai dari manfaat ekologi hingga manfaat sebagai sumber makanan dan farmasi (Nurjanah et al., 2015). Mangrove merupakan salah satu vegetasi hutan tropis dan pemanfaatan terkait potensi substansi bioaktifnya yang bernilai farmasetikal (Latief et al., 2015) belum banyak dilakukan. Mangrove merupakan tumbuhan dengan toleransi baik terhadap perubahan salinitas, tumbuh di daerah muara sungai dan daerah intertidal tropis dan subtropis. Mangrove beradaptasi terhadap tekanan lingkungan dengan mengembangkan suatu sistem pertahanan kimia yang memiliki aktivitas biologis (Agoramoorthy et al., 2008 dan Jithesh et al., 2006). Hasil penelitian melaporkan mangrove menunjukkan respons antibakteri karena mengandung komponen alkaloid, minyak atsiri, asam fenolik, flavonoid, kuinin, tannin, dan terpenoid (Ravikumar et al., 2010 dan Jithesh et al., 2006). Selain itu, telah dilaporkan sekitar 349 metabolit dari ekstrak mangrove bernilai farmakologis, seperti antibakteri dan antioksidan (Prabhu \& Guruvayoorappan, 2012).

Antibakteri merupakan substansi yang digunakan untuk mengendalikan pertumbuhan bakteri patogen. Mekanisme penghambatan terhadap pertumbuhan bakteri oleh bahan antibakteri dapat berupa perusakan dinding sel dengan cara menghambat pembentukannya atau mengubahnya setelah selesai terbentuk, perubahan membran sitoplasma sehingga menyebabkan keluarnya bahan inti dari dalam sel, perubahan molekul protein dan asam nukleat, penghambatan kerja enzim, dan penghambatan sintesis asam nukleat dan protein (WHO, 2014). Substansi antibakteri dapat bekerja secara bakteriostatik, bakteriosidal, dan bakteriolitik berdasarkan sifat toksisitas selektifnya (Parekh \& Chanda, 2007). Hasil penelitian telah melaporkan munculnya strain bakteri yang resisten terhadap agen antimikroba yang telah ada (Levy \& Marshall, 2004). Resistensi terhadap agen antibakteri meningkatkan risiko ancaman terhadap kesehatan manusia dari bakteri patogen.

Antioksidan merupakan substansi yang dapat menghambat atau mencegah oksidasi sel (Halliwell \& Whiteman, 2004). Antioksidan berfungsi melindungi sel dari kerusakan yang disebabkan oleh radikal bebas karena subtansi antioksidan dapat memberikan elektronnya pada molekul radikal bebas agar menjadi stabil (Lobo et al., 2010 dan PhamHuy et al., 2008). Antioksidan merupakan substansi yang penting bagi kesehatan manusia. Substansi antioksidan penunjang kesehatan manusia terhadap berbagai macam penyakit, seperti arterosklerosis, kardiovaskular, menghambat proses aging dan pengobatan dalam terapi kanker (Loo et al., 2007). Moskovitz, Yim, \& Chock (2002) menyatakan penyakit manusia seperti aging, kanker, inflamasi, kardiovaskular dan neurodegenerative erat hubungannya dengan oksidasi sel karena radikal bebas. Oleh karena itu, substansi antioksidan sangat dibutuhkan sebagai suplemen dalam melindungi tubuh serta membantu menyembuhkan beragam penyakit manusia (Gao \& Xiao, 2012).

Propinsi Sulawesi Tengah memiliki luas hutan mangrove sebesar 26.536,1 Ha yang tersebar di Kabupaten Donggala, Poso, Banggai, Buol, Toli-Toli, Morowali, Banggai Kepulauan, Touna dan Parigi Moutong (Jabir, 2014). Penelitian sebelumnya telah melaporkan potensi antibakteri dan antioksidan dari ekstrak daun mangrove yang dikoleksi dari Teluk Palu, Sulawesi Tengah, yaitu potensi ekstrak etanol dan etil asetat daun mangrove Avicennia sp. yang menunjukkan aktivitas antibakteri yang moderat terhadap Escherichia coli dan Staphylococcus aureus (Alhaddad et al., 2019), dan potensi antioksidan moderat 
sampai sangat kuat dari ekstrak etanol daun mangrove Rhizophora sp., Sonneratia sp., dan Avicennia sp., yang dikoleksi dari Teluk Palu dengan nilai $\mathrm{IC}_{50} 46.05 \pm 0.18$ sampai 103.95 $\pm 0.38 \mu \mathrm{g} / \mathrm{ml}$ (Dewanto et al., 2018). Akan tetapi, potensi antibakteri dan antioksidan dari mangrove yang dikoleksi dari pesisir Teluk Tomini, kabupaten Parigi Moutong, Sulawesi Tengah belum pernah dilaporkan. Damanik \& Djamaludin (2012) melaporkan luas vegetasi mangrove Tahun 2010 di kabupaten Parigi Moutong 3.127,98 Ha. Salah satu jenis mangrove yang vegetasinya tersebar di kabupaten Parigi Moutong, yaitu Rhizophora apiculata (Naharuddin, 2020 dan Lisna et al., 2017).

Oleh karena itu, penelitian ini mengevaluasi potensi antibakteri dan antioksidan ekstrak daun mangrove Rhizophora apiculata yang dikoleksi dari pesisir Teluk Tomini. Perbedaan lokasi sampling daun mangrove dapat mempengaruhi potensi aktivitas biologis dan komposisi substansi bioaktif dari suatu organisme (Cheng \& Cheng, 2015 dan Mudgal et al., 2013). Dengan melihat manfaat dan potensi mangrove yang dikoleksi dari pesisir pantai Sulawesi Tengah, maka tujuan penelitian ini, yaitu mendapatkan profil senyawa ekstrak daun mangrove $R$. apiculata yang menunjukkan aktivitas antioksidan dan menghambat pertumbuhan bakteri patogen Listeria monocytogenes, Salmonella typhimurium, dan Pseudomonas aeruginosa.

\section{MATERI DAN METODE Lokasi Pengambilan Sampel}

Teluk Tomini merupakan salah satu teluk terbesar di Indonesia, dengan luas perairan kira-kira 6 juta $\mathrm{Ha}$ (Damanik \& Rignolda, 2012). Teluk Tomini dikelilingi oleh 3 wilayah provinsi, yaitu Sulawesi Utara, Gorontalo, dan Sulawesi Tengah dan 14 kabupaten/kota. Kabupaten Parigi Moutong merupakan salah satu Kabupaten yang terletak di Sulawesi Tengah, Indonesia dan memiliki vegetasi hutan mangrove. Pengambilan sampel daun mangrove $R$. apiculata dikoleksi dari wilayah pesisir Teluk Tomini di Desa Laemanta, Kabupaten Parigi Moutong, Sulawesi Tengah, Indonesia pada koordinat $0^{\circ} 11^{\prime} 05.6$ " LS dan $120^{\circ} 00^{\prime} 32.9^{\prime \prime} \mathrm{BT}$.

\section{Bahan yang Digunakan}

Nutrient agar (Merck), nutrient broth (Merck), bacteriological agar (Hi-media), akuades, diklorometana (Merck), metanol (Merck), 1,1Diphenyl-2-picrylhydrazyl, radikal bebas (DPPH, Merck), asam galat, $\mathrm{Na}_{2} \mathrm{CO}_{3}$ yang dibeli dari CV. Amani Media Malang and CV. Intraco Makassar, Indonesia.

\section{Sampel Daun Mangrove}

Pengambilan sampel daun mangrove $R$. apiculata dilakukan pada bulan April 2020 pada kondisi cuaca cerah dan cahaya matahari terik. Sampel daun mangrove diambil secara acak dari satu pohon mangrove $R$. apiculata. Identifikasi mangrove menggunakan pedoman Noor et al., (2006) dengan mengamati karakteristik bentuk, ujung daun, jenis akar, buah, dan bunga.

\section{Ekstraksi}

Sebanyak $500 \mathrm{~g}$ sampel daun mangrove $R$. apiculata dikeringkan dengan menggunakan oven (Finco OV50) pada suhu $60^{\circ} \mathrm{C}$. Setelah kering, sampel dihaluskan sampai menjadi tepung. Lalu $100 \mathrm{~g}$ tepung daun $R$. apiculata dimaserasi dalam metanol: diklorometana (1: 1) selama 48 jam (Putra et al., 2016 dan Hsiao et al., 2015). Setelah itu disaring dan dikeringkan dengan Rotary Vacuum Evaporator (EYELA N-1100). Proses maserasi dilakukan sebanyak tiga kali. Kemudian, ekstrak yang telah kering, ditimbang dan dsimpan dalam lemari pendingin.

\section{Skrining Profil Kimia dengan GC-MS}

Profil kimia dari ekstrak daun mangrove $R$. apiculata diskrining menggunakan Gas Chromatography Mass Spectrometry-GCMS (Hewlett-Packard 6890), dengan kolom Agilent 19091S-433 HP-5MS yang memiliki panjang $30 \mathrm{~m}$ dan diameter $250 \mu \mathrm{m}$. Sebanyak $1 \mu \mathrm{L}$ ekstrak daun $R$. apiculata (dilarutkan dengan metanol) diinjeksikan ke GC-MS. Gas helium digunakan sebagai gas pembawa dengan laju alir $1 \mathrm{~mL} /$ menit dan suhu oven diatur pada $325^{\circ} \mathrm{C}$. Suhu oven awal adalah $150^{\circ} \mathrm{C}$ yang ditahan pada $2^{\circ} \mathrm{C} /$ menit. Prosesi ini berjalan selama $10^{\circ} \mathrm{C} /$ menit dan kemudian ditingkatkan menjadi $240^{\circ} \mathrm{C}$ dengan waktu tahan selama 11 menit. Total waktu yang berjalan adalah 22 menit dengan rentang pemindaian adalah 50 550 amu. Skrining profil struktur kimia didasarkan pada analisis pola fragmentasi spektrum massa dan dibandingkan dengan spektrum massa pada database profil senyawa National Institute of Standards and Technology (NIST) dan Wiley.

\section{Pengujian Antibakteri}

Aktivitas antibakteri menggunakan metode difusi sumur pada cawan petri seperti yang ditunjukkan oleh Balouiri et al. (2016) dengan 
Jurnal Kelautan, 14(1), 30-42 (2021)

modifikasi. Modifikasi dilakukan dengan menambahkan komposisi nutrient agar dari 2 $\mathrm{g}$ dengan $2 \mathrm{~g}$ agar bakteriologis dalam $100 \mathrm{~mL}$ akuades sebagai media dasar. Metode difusi sumur menggunakan dua lapisan media, yaitu lapisan media dasar dan lapisan media pembenihan. Media dasar dibuat dengan cara melarutkan nutrient agar dan agar bakteriologis, lalu disterilkan dan dituang ke cawan petri. Lapisan media pembenihan dibuat dari $70 \%$ nutrient agar dalam $100 \mathrm{~mL}$ akuades, kemudian dimasukkan ke dalam tabung berisi $9 \mathrm{~mL}$, dan disterilkan. Selanjutnya, pada media pembenihan hangat ditambahkan $1 \mathrm{~mL}$ bakteri uji dengan kepadatan $1 \times 10^{7}$ Koloni/mL (larutan bakteri dibandingkan dengan larutan standar McFarland-Hi-media). Isolat Listeria monocytogenes ATCC 49594, Pseudomonas aeruginosa ATCC 27853, dan Salmonella typhimurium ATCC 13311, diperoleh dari Laboratorium Mikrobiologi Fakultas Kedokteran Universitas Brawijaya Malang. Media pembenihan yang telah ditambahkan bakteri uji divorteks, lalu dituang ke atas lapisan media dasar. Setelah media agak mengeras, dibuat lubang sumur dengan jarak tertentu. Pada masing-masing sumur diisi 50 $\mu \mathrm{L}$ ekstrak daun $R$. apiculata dengan konsentrasi 50, 100, 200, 300 dan $400 \mathrm{mg} / \mathrm{mL}$, dan diinkubasi pada suhu $37^{\circ} \mathrm{C}$ selama 24 jam. Ciprofloxacin $10 \mathrm{mg} / \mathrm{mL}$ dan Pine Oil 1\% digunakan sebagai kontrol pembanding. Setelah itu diamati dan diukur zona hambatnya. Semua data pengukuran eksperimental dilakukan dalam tiga ulangan dan dinyatakan sebagai mean \pm standar deviasi $(n=3)$. Hasil pengukuran zona hambat dievaluasi berdasarkan nilai Minimum Inhibitory Concentration (MIC) dan Minimum Bactericidal Concentration (MBC) dengan metode Bloomfield (1991). Nilai MIC ditentukan dengan memplotkan antara In konsentrasi ekstrak pada sumbu $x$, sedangkan pada sumbu y merupakan nilai kuadrat zona hambat. Perpotongan dari regresi linier $y=a+$ bx dengan sumbu x sebagai nilai Mt. Nilai MIC adalah 0,25 x Mt dan nilai MBC adalah $4 \times$ MIC.

\section{Pengujian Antioksidan}

Aktivitas antioksidan ditentukan menggunakan metode penangkapan radikal bebas DPPH (Dewanto et al., 2018 dan Molyneux, 2004). Sebanyak $25 \mathrm{mg}$ ekstrak daun $R$. apiculata yang ditempatkan dalam wadah. Lalu, ditambahkan etanol sebanyak $125 \mathrm{~mL}$, sehingga diperoleh konsentrasi ekstrak 200 $\mu \mathrm{g} / \mathrm{mL}$. Setelah itu, dibuat seri pengenceran
$20,40,60,80,100 \mu \mathrm{g} / \mathrm{mL}$. Sebuah alikuot 2 $\mathrm{mL}$ dari larutan ekstrak dari tiap konsentrasi ditambahkan ke $2 \mathrm{~mL}$ larutan DPPH $50 \mu \mathrm{M}$. Campuran dihomogenisasi dan dibiarkan selama 30 menit dalam ruangan gelap pada suhu ruang, sebelum dilakukan pengukuran penyerapan radikal bebas pada panjang gelombang $517 \mathrm{~nm}$ dengan Spektrofotometer (UV-VIS spectrophotometer T90+ PG Instruments Ltd). Nilai absorbansi larutan DPPH juga diukur dan ditentukan berdasarkan nilai $\mathrm{IC}_{50}$ (The half maximal inhibitory concentration). Vitamin E digunakan sebagai kontrol pembanding. Lalu, persentase inhibisi diplot pada sumbu y dan sumbu $x$ sebagai konsentrasi ekstrak yang dilarutkan, untuk memperoleh persamaan regresi linier $(\mathrm{y}=\mathrm{a}+\mathrm{bx})$. Nilai $\mathrm{IC}_{50}$ ditentukan sebagai konsentrasi larutan ekstrak yang diperlukan untuk menangkap radikal bebas DPPH sebesar $50 \%$. Pengujian dilakukan dengan tiga kali pengulangan dan hasil pengukuran diekspresikan dengan standar deviasi. Persentase inhibisi sampel dihitung menggunakan persamaan:

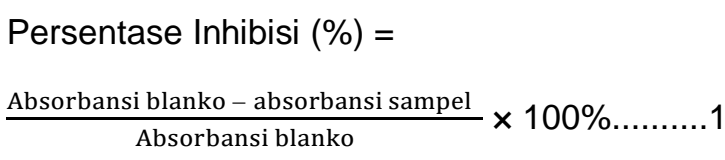

\section{Pengujian Kandungan Total Fenol}

Kandungan total fenol ekstrak daun $R$. apiculata dievaluasi berdasarkan metode Folin-Ciocalteu (Lamuela-Raventós, 2017 dan Blainski et al., 2013). Tahap pertama adalah pembuatan kurva standar asam galat, yaitu sebanyak $25 \mathrm{mg}$ asam galat ditimbang, lalu dilarutkan dengan etanol: air (1:1) sampai volume $25 \mathrm{~mL}$. Larutan asam galat dibuat dengan konsentrasi seri pengenceran 5, 20, 40, 60, 80, dan $100 \mathrm{mg} / \mathrm{L}$. Tiap konsentrasi pengenceran asam galat diambil $1 \mathrm{~mL}$ dan ditambahkan $10 \mathrm{~mL}$ aquadest. Kemudian ditambahkan $1 \mathrm{~mL}$ reagen Folin-Ciocalteu (homogenisasi). Setelah itu, didiamkan selama 8 menit, lalu ditambahkan $3 \mathrm{~mL}$ larutan $\mathrm{Na}_{2} \mathrm{CO}_{3} \quad 20 \%$ (homogenisasi). Kemudian didiamkan selama 2 jam pada suhu ruangan. Nilai absorbansi diukur pada panjang gelombang $750 \mathrm{~nm}$. Kurva standar asam galat dibuat dengan konsentrasi asam galat ( $\mathrm{mg} / \mathrm{L})$ dengan nilai absorbansi.

Tahap kedua, yaitu sebanyak $25 \mathrm{mg}$ ekstrak daun $R$. apiculata dilarutkan dengan $25 \mathrm{~mL}$ larutan etanol: air (1:1). Kemudian dari larutan ekstrak, diambil $1 \mathrm{~mL}$ dan ditambahkan $10 \mathrm{~mL}$ aquadest $+1 \mathrm{~mL}$ reagen Folin-Ciocalteu (homogenisasi). Setelah itu didiamkan selama 
8 menit dan ditambahkan $3 \mathrm{ml} \mathrm{Na} \mathrm{CO}_{3} 20 \%$ (didiamkan selama 2 jam pada suhu ruang). Kemudian diukur nilai absorbasi dari ekstrak dengan spektrofotometer UV-Vis pada panjang gelombang $750 \mathrm{~nm}$ yang memberikan warna biru. Total fenolik ditentukan dengan menggunakan persamaan regresi kurva standar asam galat.

\section{HASIL DAN PEMBAHASAN Karakteristik Sampel}

Berdasarkan karakteristik bentuk dan ujung daun, jenis akar, buah dan bunga, maka sampel daun mangrove yang digunakan dalam penelitian ini diidentifikasi sebagai Rhizophora apiculata. Pohon $R$. apiculata dapat mencapai ketinggian $30 \mathrm{~m}$ dengan diameter batang mencapai $50 \mathrm{~cm}$. Sistem perakaran $R$. apiculata memiliki bentuk yang khas hingga mencapai ketinggian $5 \mathrm{~m}$, dan kadang-kadang memiliki akar udara yang keluar dari cabang. Kulit kayu berwarna abu-abu tua. Daun $R$. apiculata seperti berkulit, berwarna hijau tua dengan hijau muda pada bagian tengah. Panjang gagang daun $R$. apiculata berukuran 17-35 mm dan warnanya kemerahan. Daun $R$. apiculata berbentuk elips menyempit, dengan ujung meruncing dan berukuran 7-19 $\times 3,5-8$ $\mathrm{cm}$. Kepala bunga $R$. apiculata kekuningan yang terletak pada gagang berukuran kurang dari $1,4 \mathrm{~cm}$, dan berjumlah 2 bunga per kelompok. Daun mahkota $R$. apiculata berjumlah 4; berwarma kuning-putih, tidak ada rambut, dan panjangnya $0,9-1,1 \mathrm{~cm}$. Kelopak

Tabel 1. Skrining profil kimia ekstrak daun Rhizophora apiculata dengan GC-MS bunga berjumlah 4, berwarna kuning kecoklatan dan melengkung.

\section{Profil Kimia Ekstrak Daun Mangrove Rhizophora apiculata}

Hasil skrining profil kimia ekstrak daun $R$. apiculata menggunakan GC-MS terdeteksi 35 puncak (29 senyawa), dengan rentang retensi time 2.756 - 21.907 menit. Akan tetapi, hanya terdapat 13 puncak (10 senyawa) dengan kualitas di atas $85 \%$. Skrining profil kimia ekstrak daun $R$. apiculata didominasi oleh senyawa mome inositol (75.6\%). Mome inositol merupakan senyawa yang banyak terdapat di tumbuhan hijau. Senyawa turunan inositol dilaporkan merupakan konstituen utama dari famili Rhizophoraceae (Richter et al., 1990). Konstituen turunan inositol juga telah dilaporkan dari $R$. mucronata dan $R$. sytlosa dengan sifat antiviral, antiulcer dan antidiabetes (Usman et al., 2019; Revathi et al., 2014; Arora et al., 2014; dan Bandaranayake, 2002). Mome inositol merupakan senyawa yang umum terkandung dalam ekstrak tumbuhan dengan sifat antibakteri dan antioksidan (Sivakumar, 2019; Sunita \& Manju, 2017; dan Venkata et al., 2012). Selain itu, mome inositol dilaporkan sebagai anti-alopecic, anti-sirosis, antineuropatik, kolesterolitik, lipotropik dan pemanis (Das et al., 2014). Hasil skrining profil kimia ekstrak daun $R$. apiculata dengan GCMS dapat dilihat pada Tabel 1.

\begin{tabular}{llccccc}
\hline No & \multicolumn{1}{c}{ Nama Senyawa } & Formula & $\begin{array}{c}\text { Berat } \\
\text { Molekul } \\
\text { (g/mol) }\end{array}$ & $\begin{array}{c}\text { Waktu } \\
\text { Retensi } \\
\text { (Menit) }\end{array}$ & $\begin{array}{c}\text { Area } \\
\text { (\%) }\end{array}$ & $\begin{array}{c}\text { Kualitas } \\
\text { (\%) }\end{array}$ \\
\hline 1 & 3-fluoro-2,5-dimethyl-2,4-hexadien & $\mathrm{C}_{6} \mathrm{H}_{8} \mathrm{OS}$ & 128,19 & 3,562 & 1,13 & 86 \\
2 & $\begin{array}{l}\text { 2-Furancarboxaldehyde, 5- } \\
\text { (hydroxymethyl)- }\end{array}$ & $\mathrm{C}_{7} \mathrm{H}_{7} \mathrm{FO}$ & 126,13 & 5,815 & 0,17 & 94 \\
3 & 2,6-Octadien-1-ol, 3,7-dimethyl- & $\mathrm{C}_{10} \mathrm{H}_{18} \mathrm{O}$ & 154,25 & 6,037 & 1,11 & 94 \\
& & & 6,181 & 0,48 & 94 \\
4 & Phenol, 2-propyl- & $\mathrm{C}_{9} \mathrm{H}_{12} \mathrm{O}$ & 136,19 & 7,780 & 0,59 & 86 \\
5 & 1,4-benzenediol, 2-(1-methylpropyl)- & $\mathrm{C}_{10} \mathrm{H}_{14} \mathrm{O}_{2}$ & 166,22 & 8,969 & 0,08 & 90 \\
6 & Trans-isoelemicin & $\mathrm{C}_{12} \mathrm{H}_{16} \mathrm{O}_{3}$ & 208,25 & 11,983 & 0,35 & 86 \\
7 & Mome inositol & $\mathrm{C}_{6} \mathrm{H}_{12} \mathrm{O}_{6}$ & 180,16 & 13,859 & 18,47 & 87 \\
& & & & 14,368 & 23,71 & 92 \\
& & & & 14,674 & 33,42 & 92 \\
9 & Neophytadiene & $\mathrm{C}_{20} \mathrm{H}_{38}$ & 278,50 & 17,518 & 1,43 & 91 \\
& & & & 18,617 & 0,37 & 89 \\
10 & $\begin{array}{l}\text { Pentadecanoic acid, 14-methyl-, methyl } \\
\text { ester }\end{array}$ & $\mathrm{C}_{17} \mathrm{H}_{34} \mathrm{O}_{2}$ & 270,50 & 21,907 & 1,21 & 99 \\
\hline
\end{tabular}




\section{Aktivitas Antibakteri}

Evaluasi aktivitas antibakteri dari ekstrak daun $R$. apiculata dilakukan dengan mengamati zona hambat yang terbentuk dari isolat $L$. monocytogenes, $S$. typhimurium, dan $P$. aeruginosa. Hasil pengukuran diameter zona hambat dari ekstrak daun mangrove $R$. apiculata dibandingkan dengan kontrol dapat dilihat pada Gambar 1.

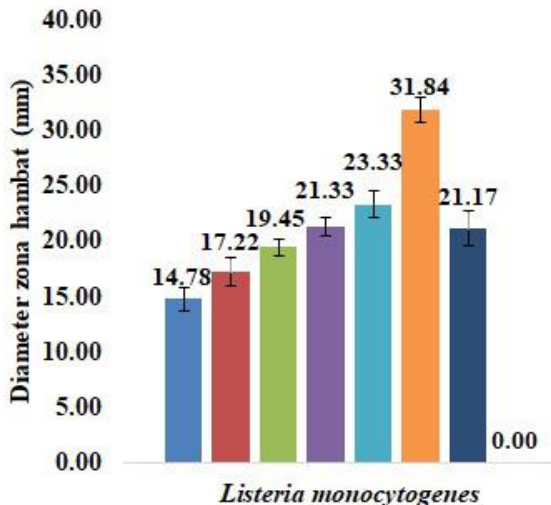

a $50 \mathrm{mg} / \mathrm{mL}$

= $400 \mathrm{mg} / \mathrm{mL}$

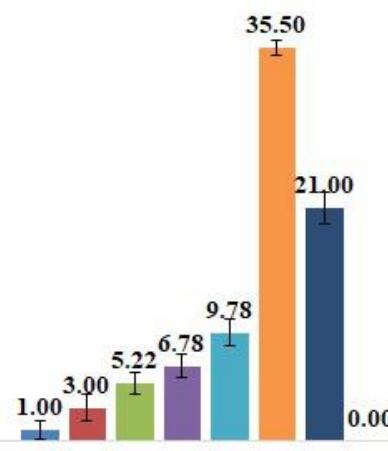

Salmonella typhimurium Bakteri Uji

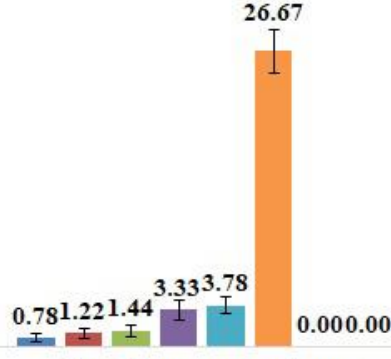

Pseudomonas aeruginosa

$=300 \mathrm{mg} / \mathrm{mL}$

- Negative (-)

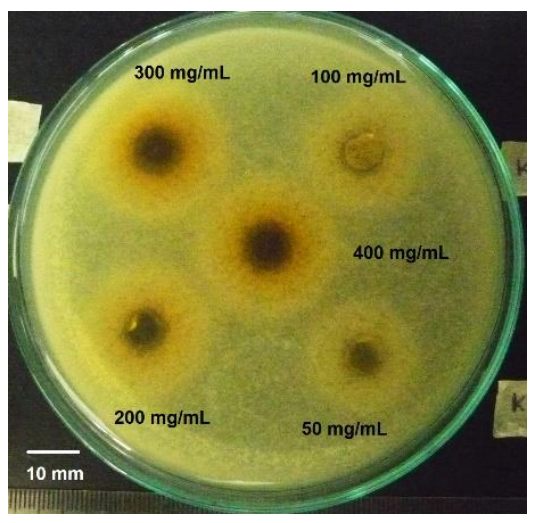

Listeria monocytogenes

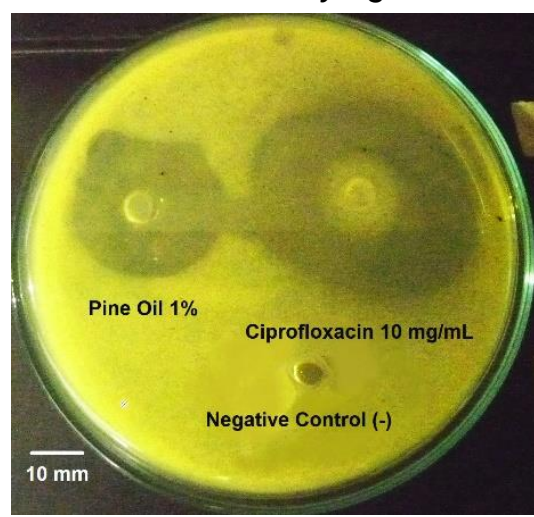

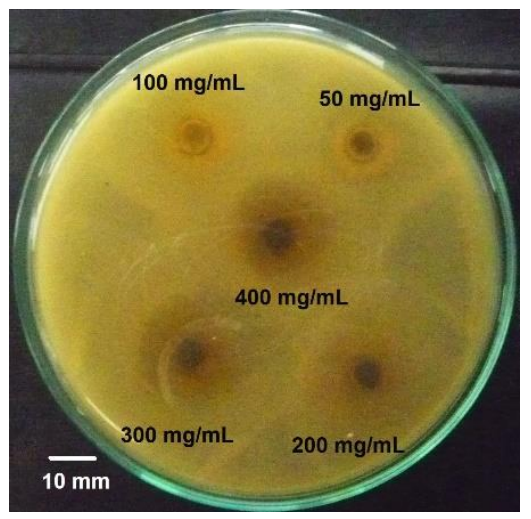

Salmonella typhimurium

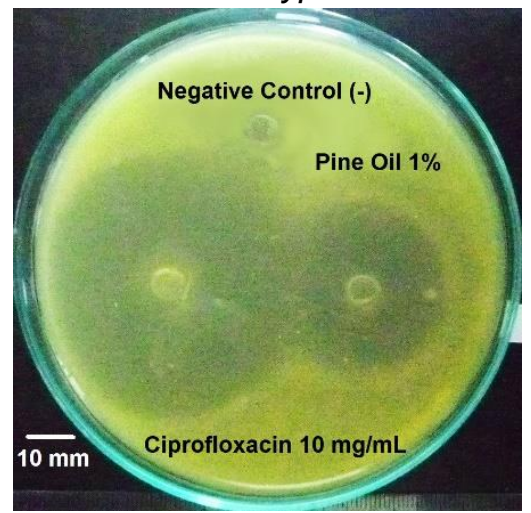

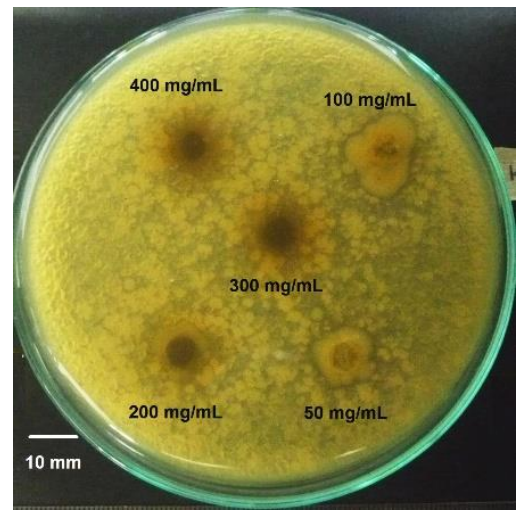

Pseudomonas aeruginosa

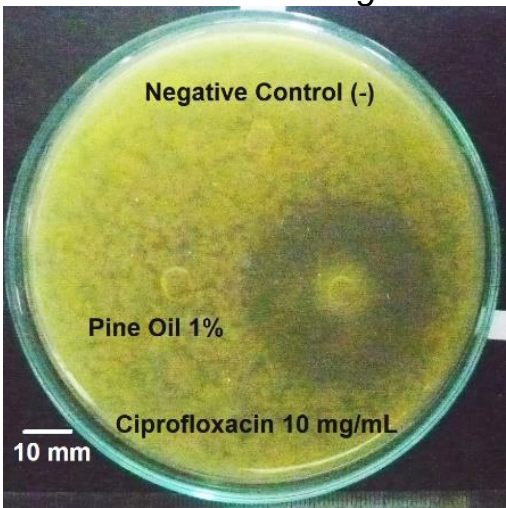

Gambar 1. Diameter Zona Hambat dari Ekstrak Daun Mangrove R. apiculata

Ekstrak daun mangrove $R$. apiculata menunjukkan ukuran zona hambat yang beragam terhadap pertumbuhan $L$. monocytogenes, $S$. typhimurium dan $P$. aeruginosa. Menurut kategori zona hambat oleh Paudel et al. (2014), terdapat empat kategori aktivitas antibakteri: sangat kuat (zona hambat $\varnothing>20 \mathrm{~mm}$ ), kuat (zona hambat, ø 15-20 mm), moderat (zona hambat $ø ~ 10-15$ $\mathrm{mm}$ ), dan lemah (zona hambat $\varnothing<10 \mathrm{~mm}$ ). Ekstrak daun mangrove $R$. apiculata menunjukkan potensi antibakteri dari sangat kuat hingga lemah terhadap bakteri $L$. 
monocytogenes, $S$. typhimurium dan $P$. aeruginosa.

Gambar 1 menunjukkan ekstrak daun $R$. apiculata lebih kuat menghambat pertumbuhan bakteri gram positif, yaitu $L$. monocytogenes daripada bakteri gram negatif, yaitu $S$. typhimurium dan $P$. aeruginosa. Hal ini diduga karena bakteri gram negatif memiliki lapisan tambahan pada struktur dinding sel yang dikenal dengan membran luar. Membran ini tersusun atas lipopolisakarida (LPS), matriks porin, dan lipoprotein. Membran khusus molekul protein (porin) pada bakteri gram negatif dapat memfasilitasi difusi pasif senyawa hidrofilik dengan berat molekul rendah. Molekul yang bersifat hidrofilik lebih mudah melewati LPS daripada yang bersifat hidrofobik (Jawetz et al., 2005). Bakteri gram negatif memiliki ujung hidrofilik yaitu karboksil, asam amino, dan hidroksil sehingga bakteri gram negatif peka terhadap senyawa antibakteri polar (Madigan et al., 2000). Resistensi bakteri gram negatif dan gram positif terhadap senyawa antibakteri berbeda. Bakteri gram negatif umumnya sensitif terhadap senyawa antibakteri polar, sedangkan bakteri gram positif lebih sensitif terhadap senyawa antibakteri non-polar (Brannen \& Davidson, 1993). Perbedaan sensitivitas bakteri gram positif dan gram negatif berkaitan dengan struktur di dalam dinding sel, seperti ketebalan peptidoglikan (adanya reseptor, pori, dan lipid), sifat ikatan silang, dan aktivitas enzim autolitik. Komponen tersebut merupakan faktor yang menentukan penetrasi, pengikatan, dan aktivitas senyawa antibakteri (Tanod et al., 2018). Evaluasi MIC dan MBC ekstrak daun $R$. apiculata terhadap tiga bakteri uji disajikan pada Tabel 2.

Tabel 2. MIC and MBC Ekstrak Daun Mangrove Rhizophora apiculata terhadap Bakteri Uji dengan Metode Bloomfield

\begin{tabular}{lcccc}
\hline \multicolumn{1}{c}{ Bakteri Uji } & Persamaan regresi & $\mathbf{R}^{2}$ & MIC $(\mathbf{m g} / \mathbf{m L})$ & $\mathbf{M B C}(\mathbf{m g} / \mathbf{m L})$ \\
\hline Listeria monocytogenes & $\mathrm{y}=148.79 \mathrm{x}-380.61$ & 0.96 & 0.64 & 2.56 \\
Salmonella typhimurium & $\mathrm{y}=39.364 \mathrm{x}-165.08$ & 0.77 & 1.05 & 4.19 \\
Pseudomonas aeruginosa & $\mathrm{y}=6.4161 \mathrm{x}-26.825$ & 0.74 & 1.05 & 4.18
\end{tabular}

Tabel 2 menunjukkan terdapat perbedaan minimum inhibitory concentration dan minimum bacteriocidal concentration antara bakteri uji. Perbedaan ini disebabkan perbedaan komposisi dinding sel. Bakteri $L$. monocytogenes merupakan bakteri Gram positif, sedangkan $S$. typhimurium dan $P$. aeruginosa termasuk bakteri Gram negatif. Bakteri Gram postitif memiliki dinding sel dengan lapisan peptidoglikan tebal yang relatif mudah rusak, sehingga agen antibakteri dapat melewatinya dengan cukup mudah. Sedangkan pada bakteri Gram negatif meskipun dinding selnya memiliki lapisan peptidoglikan yang tipis, akan tetapi dilindungi oleh membran luar. Membran luar pada bakteri Gram-negatif menjadi penghalang yang efektif, mengatur jalannya molekul besar seperti agen antibakteri ke dalam sel. Sebaliknya, lapisan peptidoglikan berpori yang tebal pada dinding sel bakteri Gram-positif memberikan akses yang lebih besar ke agen antibakteri (Breijyeh et al., 2020; Zhang et al., 2018; Mai-Prochnow et al., 2016).

Pengujian aktivitas antibakteri pada penelitian ini menggunakan ciprofloxacin $10 \mathrm{mg} / \mathrm{mL}$ dan pine oil $1 \%$ sebagai kontrol pembanding. Ciprofloxacin $10 \mathrm{mg} / \mathrm{mL}$ menunjukkan kemampuan menghambat ketiga bakteri uji dengan kategori sangat kuat. Ciprofloxacin merupakan agen antibakteri yang termasuk golongan fluorokuinolonagen. Ciprofloxacin bersifat stabil dan berdifusi dengan baik pada media agar. Ciprofloxacin merupakan agen antibakteri spektrum luas dan dapat menghambat sebagian besar jenis bakteri patogen (Jin et al., 2019). Ciprofloxacin efektif melawan bakteri Gram-negatif, tetapi kurang efektif melawan bakteri Gram-positif (Marfuati et al., 2017). Chalkley \& Koornhof (1985) melaporkan ciprofloxacin dapat membunuh $S$. aureus pada konsentrasi $0.5 \mu \mathrm{g} / \mathrm{mL}$. Ciprofloxacin dilaporkan dapat menghambat pertumbuhan $E$. coli, $S$. aureus, dan $P$. aueruginosa (Mughal et al., 2009), sedangkan (Masadeh et al., 2014) melaporkan ciprofloxacin menghambat $E$. coli dengan baik.

Bila dibandingkan dengan ekstrak $R$. apiculata, hasil pengujian menunjukkan ekstrak daun $R$. apiculata dapat menghambat dengan baik $L$. monocytogenes yang merupakan bakteri Gram positif. Hal ini didukung dengan hasil penelitian yang melaporkan ekstrak pranajiwa (Euchresta horsfieldii) yang didominasi oleh senyawa mome inositol, efektif dalam menghambat bakteri Gram positif Staphylococcus aureus (Prihantini et al., 2018). Pine oil merupakan bahan aktif dari tumbuhan pinus. Fekih et al. (2014) melaporkan minyak dari tumbuhan 
Jurnal Kelautan, 14(1), 30-42 (2021)

pinus didominasi oleh senyawa

monoterpenoid. Ekstrak pinus dilaporkan efektif menghambat bakteri Gram postif seperti L. monocytogenes (Tillah et al., 2017). Hasil pengujian menunjukkan pine oil tidak mampu menghambat pertumbuhan $P$. aeruginosa. Hasil pengujian ini didukung oleh Sulistyaningsih et al. (2012) yang melaporkan pine oil $2,5 \%$ tidak efektif menghambat pertumbuhan $P$. aeruginosa. Hal ini diduga karena $P$. aeruginosa merupakan bakteri dengan kombinasi sifat ketahanan alami terhadap agen antibakteri dan kemampuan memperoleh sifat resistensi baru melalui mutasi (Stover et al., 2000). Bila dibandingkan dengan kontrol pembanding, ekstrak $R$. apiculata 300 dan $400 \mathrm{mg} / \mathrm{mL}$ cukup menjanjikan dalam menghambat bakteri Gram postif, karena menunjukkan kekuatan yang hampir sebanding dengan kekuatan pine oil $1 \%$ dan ciprofloxacin $10 \mathrm{mg} / \mathrm{mL}$.

Hasil penelitian sebelumnya telah membuktikan bahwa ekstrak daun mangrove genus Rhizopora sebagai antibakteri, yaitu $R$. mucronata dilaporkan menghambat $S$. aureus, E. coli dan Klebsiella pneumoniae (Mangrio et al., 2016 dan Nurdiani et al., 2012), $P$. aeruginosa (Tarman et al., 2013), Streptococcus sp., Proteus vulgaris, Proteus mirabilis dan Salmonella typhi (Sahoo et al., 2012). Ekstrak daun R. mangle dilaporkan dapat menghambat $S$. aureus, $S$. typhi, Mycobacterium smegmatis, Bacillus subtilis, $P$. aeruginosa dan E. coli (Cruz et al., 2015). Sedangkan pada ekstrak butanol $R$. apiculata dilaporkan menunjukkan efek antibakteri yang kuat terhadap Corynebacterium sp., S. aureus, dan Vibrio cholera, ekstrak heksan menunjukkan daya hambat terhadap Corynebacterium sp. dan Mycobacterium sp., sedangkan ekstrak methanol dan kloroform menunjukkan efek antibakteri moderat terhadap E. coli, V. cholerae, Salmonella sp., Corynebacterium sp., $S$. aureus, $P$. aeruginosa, Shigella sp., Klebsiella sp., Enterobacter sp. dan Mycobacterium sp. (Ramalingam \& Rajaram, 2018).

\section{Pengujian Aktivitas Antioksidan}

Penelitian ini juga mengevaluasi aktivitas antioksidan ekstrak daun $R$. apiculata menggunakan metode penangkapan radikal DPPH. Penurunan intensitas cahaya ungu radikal DPPH, berbanding lurus dengan peningkatan konsentrasi radikal DPPH. Reduksi warna ungu DPPH disebabkan oleh reaksi molekul hidrazil difenil-2-pikril dengan atom hidrogen yang dilepaskan oleh komponen molekul ekstrak, sehingga terbentuk senyawa hidrazin difenil pikril dan menyebabkan DPPH berubah warna dari ungu menjadi kuning (Huliselan et al., 2015). Aktivitas antioksidan menunjukkan kemampuan suatu substansi bioaktif dalam menghambat reaksi oksidasi yang dinyatakan sebagai persentase penghambatan (Dewanto et al., 2019). Pada penelitian ini dilakukan pengukuran persentase penangkapan radikal DPPH untuk ekstrak daun mangrove $R$. apiculata dan vitamin $E$ digunakan sebagai kontrol pembanding, seperti yang dapat dilihat pada Gambar 2.

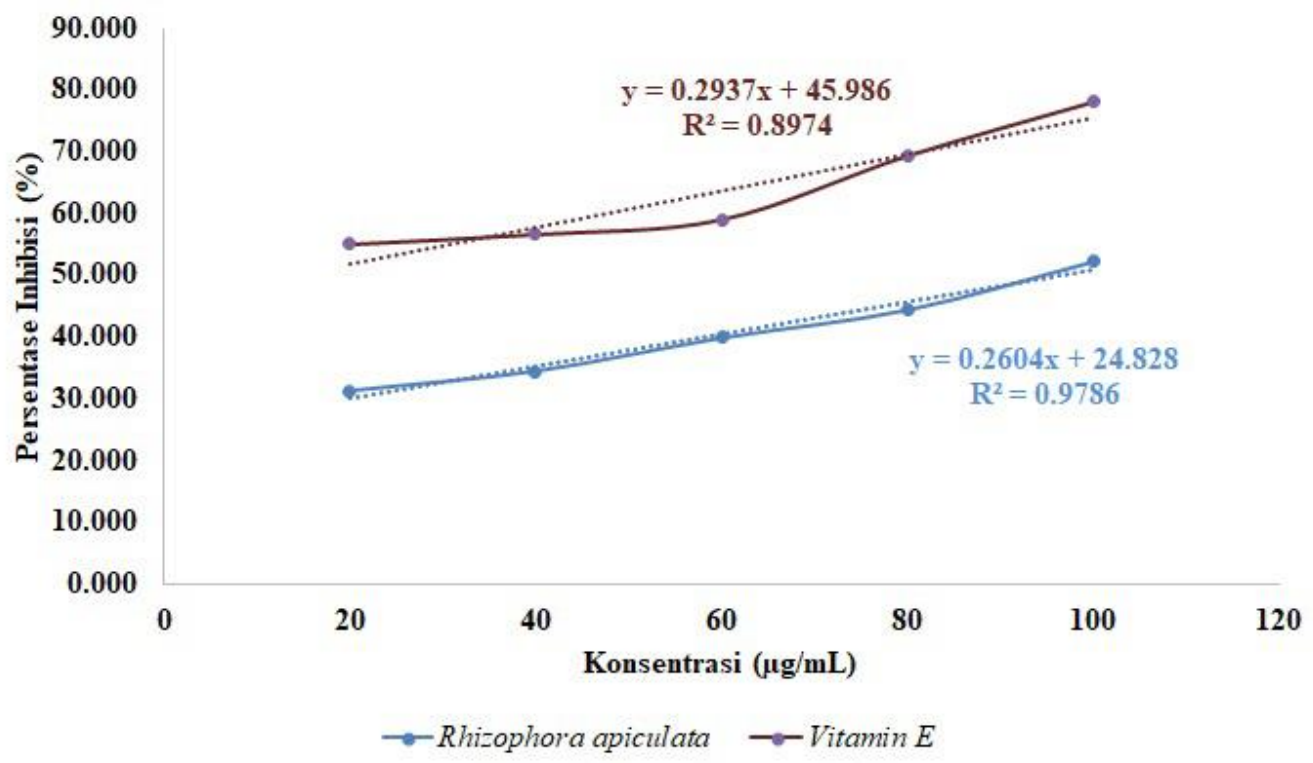

Gambar 2. Persentase Inhibisi Ekstrak Daun Mangrove Rhizophora apiculata dibandingkan dengan vitamin $\mathrm{E}$ 
Ekstrak daun $R$. apiculata dievaluasi juga efek inhibisi radikal $\mathrm{DPPH}$ untuk penentuan $\mathrm{IC}_{50}$ (Tabel 3). Ekstrak daun $R$. apiculata menunjukkan aktivitas antioksidan karena mampu mendonasikan atom hidrogen/ elektron untuk bereaksi dengan radikal DPPH. Menurut Blois (1958) terdapat empat kategori aktivitas antioksidan: sangat kuat $\left(\mathrm{IC}_{50}<50\right.$ $\mu \mathrm{g} / \mathrm{mL})$, kuat (IC 50 antara 50-100 $\mu \mathrm{g} / \mathrm{mL})$, sedang ( $\mathrm{IC}_{50}$ berkisar antara 100-150 $\left.\mu \mathrm{g} / \mathrm{mL}\right)$ dan lemah ( $\mathrm{IC}_{50}$ berkisar antara 150-200 $\mu \mathrm{g} / \mathrm{mL}$ ). Hasil pengujian menunjukkan bahwa peningkatan konsentrasi ekstrak meningkatkan persentase inhibisi radikal DPPH.

Tabel 3. Nilai $\mathrm{IC}_{50}$ dari Ekstrak Daun Mangrove Rhizophora apiculata dengan menggunakan Metode Penangkapan Radikal DPPH, dibandingkan dengan vitamin E.

\begin{tabular}{ll}
\hline \multicolumn{1}{c}{ Ekstrak Daun } & IC $_{50}(\mu \mathrm{g} / \mathrm{mL})$ \\
\hline Rhizophora apiculata & $96.68 \pm 0.58$ \\
Vitamin E & $15.87 \pm 4.47$ \\
\hline
\end{tabular}

Hasil penelitian ini didukung dengan hasil penelitian sebelumnya yang melaporkan potensi antioksidan dari ekstrak mangrove genus Rhizophora, yaitu ekstrak etanol, butanol, etil ester, dan air dari $R$. apiculata dengan kisaran $\mathrm{IC}_{50} 9.68 \pm 1.86$ sampai 23.72 $\pm 1.94 \mu \mathrm{g} / \mathrm{mL}$ pada konsentrasi DPPH 0,1 nM (Gao \& Xiao, 2012). Selain itu esktrak daun $R$. mangle menunjukkan nilai $\mathrm{IC}_{50} \quad 0.15 \pm 0.02$ $\mathrm{mg} / \mathrm{ml}$ pada konsentrasi DPPH 0.0219\% (Cruz et al., 2015). Ekstrak daun $R$. apiculata dilaporkan $\mathrm{IC}_{50}$ pada kisaran 6-7 $\mu \mathrm{g} / \mathrm{mL}$ pada konsentrasi DPPH $125 \mu \mathrm{M}$ (Wahyuni et al., 2015). Ekstrak mangrove $R$. apiculata dilaporkan menunjukkan $84 \%$ penangkapan radikal DPPH (1 $\mathrm{mM})$ (Ramalingam \& Rajaram, 2018). Senyawa polyisoprenoid dari daun $R$. mucronata menunjukkan $I_{50} 27620$ $\mu \mathrm{g} / \mathrm{mL}$ pada konsentrasi DPPH $60 \mu \mathrm{g} / \mathrm{mL}$ (Sumardi et al., 2018). Ekstrak metanol dan etil asetat ekstrak daun $R$. apiculata dilaporkan $\mathrm{IC}_{50}$ berkisar 80-100 ppm pada konsentrasi DPPH 0.1 mM (Ridlo et al., 2019) Ekstrak daun $R$. mucronata menunjukkan nilai $\mathrm{IC}_{50}$ $6.65 \pm 0.10 \mu \mathrm{g} / \mathrm{mL}$ pada konsentrasi $\mathrm{DPPH}$ $0.135 \mathrm{mM}$ (Adhikari et al., 2016).

Vitamin $E$ sebagai kontrol pembanding memiliki satu gugus hidroksil. Pengujian menunjukkan vitamin $E$ merupakan agen antioksidan yang sangat kuat. Dari studi literatur, nilai $\mathrm{IC}_{50}$ vitamin $\mathrm{E}$ berkisar antara 0.72 - $23 \mu \mathrm{g} / \mathrm{mL}$, tergantung dari konsentrasi DPPH yang digunakan (Cruz et al., 2015; Cheng et al., 2013; Melannisa et al., 2011; Da'i \& Triharman, 2010; Yassa et al., 2009; dan Rohman et al., 2007).

\section{Pengujian Kandungan Total Fenol}

Hasil pengujian kandungan total fenol dari ekstrak daun $R$. apiculata sebesar $3646.53 \pm$ $7.00 \mathrm{mg}$ GAE/g ekstrak kering, dengan persamaan regresi asam galat $\mathrm{y}=0.0101 \mathrm{x}-$
0.0318. Penelitian sebelumnya melaporkan kandungan total fenol ekstrak etanol dan etil asetat daun $R$. apiculata sebesar $50-60 \mathrm{mg}$ GAE/g (Ridlo et al., 2019).

Mangrove adalah tumbuhan habitat pasang surut, mengalami variasi harian dalam tekanan abiotik yang dapat mempengaruhi proses morfologi, fisiologis, biokimia dan molekuler secara negatif (Dasgupta et al., 2012). Variasi tekanan lingkungan dapat memicu produksi reactive oxygen species (ROS). Substansi antioksidan dan antibacterial yang terdapat pada tanaman mangrove diduga merespon variasi tekanan lingkungan dan memproduksi subtansi yang dapat menstabilkan ROS (Thatoi et al., 2014). Dengan demikian, mengindikasikan daun mangrove $R$. apiculata merupakan sumber potensial senyawa antibakteri dan antioksidan yang dapat dimanfaatkan sebagai sumber sediaan fitofarmaka yang bermanfaat bagi kesehatan manusia.

\section{KESIMPULAN DAN SARAN}

Penelitian ini telah mengeksplorasi potensi antibakteri dan antioksidan ekstrak daun Rhizophora apiculata. Hasil skrining profil kimia dari ekstrak daun $R$. apiculata dilaporkan didominasi senyawa mome inositol. Ekstrak daun $R$. apiculata $300 \mathrm{mg} / \mathrm{mL}$ menunjukkan kemampuan yang potensial dalam menghambat bakteri Gram positif Listeria monocytogenes. Ekstrak daun $R$. apiculata memperlihatkan efek antioksidan dengan $\mathrm{IC}_{50}$ $96.68 \pm 0.58 \mu \mathrm{g} / \mathrm{mL}$ pada konsentrasi $\mathrm{DPPH}$ $50 \mu \mathrm{M}$ dan kandungan total fenol sebesar $3646.53 \pm 7.00 \mathrm{mg} \mathrm{GAE} / \mathrm{g}$. Oleh karena itu, ekstrak daun $R$. apiculata perlu dipurifikasi dan diidentifikasi lebih lanjut kandungan senyawa bioaktfnya, karena masih terdapat 22 puncak dari analisis GC-MS dengan kualitas dibawah $85 \%$. 


\section{UCAPAN TERIMA KASIH}

Semua penulis mengucapkan terima kasih kepada Direktorat Riset dan Pengabdian kepada Masyarakat, Deputi Penguatan Riset dan Pengembangan, Kementerian Riset dan Teknologi / Badan Riset dan Inovasi Nasional, Republik Indonesia yang telah membiayai penelitian ini melalui hibah penelitian skema penelitian dosen pemula tahun 2020 (No. 189/SP2H/AMD/LT/DRPM/2020). Para penulis juga mengucapkan terima kasih kepada Ketua Sekolah Tinggi Perikanan dan Kelautan Palu yang telah memberikan fasilitas dan dukungan untuk menyelesaikan penelitian ini. Tidak lupa juga semua penulis juga berterima kasih kepada Siti Khalimatu Sa'diah, S.Pi., Fatma, S.Pi., dan Moh. Ahdiat, S.Pi. yang membantu pengujian di laboratorium.

\section{DAFTAR PUSTAKA}

Adhikari, A., Ray, M., Das, A. K., \& Sur, T. K. (2016). Antidiabetic and antioxidant activity of Rhizophora mucronata leaves (Indian sundarban mangrove): An in vitro and in vivo study. Ayu, 37(1), 76.

Agoramoorthy, G., Chen, F. A., Venkatesalu, V., Kuo, D. H., \& Shea, P. C. (2008). Evaluation of antioxidant polyphenols from selected mangrove plants of India. Asian Journal of Chemistry, 20(2), 1311.

Alhaddad, Z. A., Tanod, W. A., \& Wahyudi, D. (2019). BIOAKTIVITAS ANTIBAKTERI DARI EKSTRAK DAUN MANGROVE Avicennia sp. Jurnal Kelautan: Indonesian Journal of Marine Science and Technology, 12(1), 12-22.

Arora, K., Nagpal, M., Jain, U., Jat, R. C., \& Jain, S. (2014). Mangroves: A novel gregarious phyto medicine for diabetes. International Journal of Research and Development in Pharmacy \& Life Sciences, 3(6), 1231-1244.

Balouiri, M., Sadiki, M., \& Ibnsouda, S. K. (2016). Methods for in vitro evaluating antimicrobial activity: A review. Journal of pharmaceutical analysis, 6(2), 71-79.

Bandaranayake, W. M. (2002). Bioactivities, bioactive compounds and chemical constituents of mangrove plants. Wetlands ecology and management, 10(6), 421-452.

Blainski, A., Lopes, G. C., \& De Mello, J. C. P. (2013). Application and analysis of the folin ciocalteu method for the determination of the total phenolic content from Limonium brasiliense $\mathrm{L}$. Molecules, 18(6), 6852-6865.

Blois, M. S. (1958). Antioxidant determinations by the use of a stable free radical. Nature, 181(4617), 1199-1200.

Bloomfield, S. F. (1991). Methods For Assesing Antimicrobial Activity In Mechanism of Action of Chemical Biocides Thesis Study and Explanation.(S.. Denyer \& BW Hogo, Eds.).

Brannen, A., \& Davidson, P. (1993). Antimicrobial in foods. Marcel Dekker. New York.

Breijyeh, Z., Jubeh, B., \& Karaman, R. (2020). Resistance of Gram-negative bacteria to current antibacterial agents and approaches to resolve it. Molecules, 25(6), 1340.

Chalkley, L. J., \& Koornhof, H. J. (1985). Antimicrobial activity of ciprofloxacin against Pseudomonas aeruginosa, Escherichia coli, and Staphylococcus aureus determined by the killing curve method: antibiotic comparisons and synergistic interactions. Antimicrobial agents and chemotherapy, 28(2), 331342.

Cheng, F., \& Cheng, Z. (2015). Research progress on the use of plant allelopathy in agriculture and the physiological and ecological mechanisms of allelopathy. Frontiers in plant science, 6, 1020.

Cheng, K. C., Wu, J. Y., Lin, J. T., \& Liu, W. H. (2013). Enhancements of isoflavone aglycones, total phenolic content, and antioxidant activity of black soybean by solid-state fermentation with Rhizopus spp. European Food Research and Technology, 236(6), 1107-1113.

Cruz, S. M., Marroquín, N., Alvarez, L. E., Chang, D. E., \& Cáceres, A. (2015). Evaluation of Mangrove (Rhizophora mangle L.) products as coloring, antimicrobial and antioxidant agents. International Journal of Phytocosmetics and Natural Ingredients, 2(1), 12-12.

Da'i, M., \& Triharman, F. (2010). Uji aktivitas penangkap radikal DPPH (1, 1-difenil-2pikrilhidrazil) isolat alfa mangostin kulit buah manggis (Garcinia mangostana L.).

Damanik, R., \& Rignolda, D. (2012). Atlas Mangrove Teluk Tomini. Sustainable Coastal Livelihoods and Management Program. Makassar.

Das, S., Vasudeva, N., \& Sharma, S. (2014). Chemical composition of ethanol extract of Macrotyloma uniflorum (Lam.) Verdc . using GC-MS spectroscopy. Organic and Medicinal Chemistry Letters, 4(13).

Dasgupta, N., Nandy, P., Sengupta, C., \& Das, S. (2012). Protein and enzymes regulations towards salt tolerance of 
some Indian mangroves in relation to adaptation. Trees - Structure and Function, 26(2), 377-391.

Dewanto, D. K., Finarti, F., Hermawan, R., Ndobe, S., Riyadi, P. H., \& Tanod, W. A. (2019). Aktivitas antioksidan ekstrak karang lunak asal Teluk Palu, Sulawesi Tengah, Indonesia. Jurnal Pascapanen Dan Bioteknologi Kelautan Dan Perikanan, 14(2), 163-178.

Dewanto, D. K., Tanod, W. A., Finarti, F., \& Renol, R. (2018). Screening of antiradical activity from some central Sulawesi mangroves. Pharmaciana, 8(1), 155168.

Fekih, N., Allali, H., Merghache, S., Chaïb, F., Merghache, D., El Amine, M., Djabou, N., Muselli, A., Tabti, B., \& Costa, J. (2014). Chemical composition and antibacterial activity of Pinus halepensis Miller growing in West Northern of Algeria. Asian Pacific Journal of Tropical Disease, 4(2), 97-103.

Gao, M., \& Xiao, H. (2012). Activity-guided isolation of antioxidant compounds from Rhizophora apiculata. Molecules, 17(9), 10675-10682.

Halliwell, B., \& Whiteman, M. (2004). Measuring reactive species and oxidative damage in vivo and in cell culture: how should you do it and what do the results mean? British Journal of Pharmacology, 142(2), 231-255.

Hsiao, T.-H., Sung, C.-S., Lan, Y.-H., Wang, Y.-C., Lu, M.-C., Wen, Z.-H., Wu, Y.-C., \& Sung, P.-J. (2015). New antiInflammatory cembranes from the cultured soft coral Nephthea columnaris. Marine Drugs, 13(6), 3443-3453.

Huliselan, Y. M., Runtuwene, M. R. J., \& Wewengkang, D. S. (2015). Antioxidant activity of ethanol, ethyl acetate and nhexane extract from seswanua leaves (Clerodendron squamatum Vahl.). Pharmacon, 4(3), 155-163.

Jabir, M. (2014). Peran masyarakat terhada pengelolaan ekosistem hutan mangrove di kelurahan kabonga besar Kecamatan Banawa Kabupaten Donggala. GeoTadulako, 2(4), 1-17.

Jawetz, Melnick, \& Adelberg. (2005). Mikrobiologi kedokteran. (Edisi Ke-2). EGC Buku Kedokteran. Jakarta.

Jin, C., Gibani, M. M., Pennington, S. H., Liu, X., Ardrey, A., Aljayyoussi, G., Moore, M., Angus, B., Parry, C. M., Biagini, G. A., Feasey, N. A., \& Pollard, A. J. (2019). Treatment responses to azithromycin and ciprofloxacin in uncomplicated Salmonella typhi infection: A comparison of clinical and microbiological data from a controlled human infection model. PLOS Neglected Tropical Diseases, 13(12), e0007955.

Jithesh, M. N., Prashanth, S. R., Sivaprakash, K. R., \& Parida, A. K. (2006). Antioxidative response mechanisms in halophytes: Journal of Genetics, 85(3), 237-254.

Lamuela-Raventós, R. M. (2017). FolinCiocalteu method for the measurement of total phenolic content and antioxidant capacity. In R. Apak, E. Capanoglu, \& F. Shahidi (Eds.), Measurement of Antioxidant Activity and Capacity: Recent Trends and Applications (First, pp. 107115). John Wiley \& Sons Ltd.

Latief, M., Nazarudin, \& Nelson. (2015). Aktivitas antioksidan ekstrak daun dan buah prepat (Sonneratia alba) Asal Tanjung Jabung Timur Propinsi Jambi. SEMIRATA 2015 Bidang MIPA BKS-PTN Barat Universitas Tanjungpura, Pontianak, 171-179.

Levy, S. B., \& Marshall, B. (2004). Antibacterial resistance worldwide: causes, challenges and responses. Nature Medicine, 10(12), S122-S129.

Lisna, Malik, A., \& Toknok, B. (2017). Potensi vegetasi hutan mangrove di wilayah pesisir pantai desa khatulistiwa kecamatan Tinombo Selatan Kabupaten Parigi Moutong. Warta Rimba, 5(1), 6370.

Lobo, V., Patil, A., Phatak, A., \& Chandra, N. (2010). Free radicals, antioxidants and functional foods: Impact on human health. Pharmacognosy Reviews, 4(8), 118-126.

Loo, A. Y., Jain, K., \& Darah, I. (2007). Antioxidant and radical scavenging activities of the pyroligneous acid from a mangrove plant, Rhizophora apiculata. Food Chemistry, 104(1), 300-307.

Madigan, M. ., Martinko, J., \& Parker, J. (2000). Brock Biology of Microorganisms (9th ed.). Prentice-Hall Inc.

Mai-Prochnow, A., Clauson, M., Hong, J., \& Murphy, A. B. (2016). Gram positive and Gram negative bacteria differ in their sensitivity to cold plasma. Scientific Reports, 6(38610), 1-11.

Mangrio, A., Rafiq, M., Naqvi, S. H., Junejo, S., Mangrio, S., \& Rind, N. (2016). Evaluation of phytochemical constituents and antibacterial potential of Avicennia marina and Rhizopora mucronata from Indus Delta of Pakistan. Pakistan Journal of Biotecnology, 13(4), 259-265.

Marfuati, N., Rakhmawatie, M. D., \& Akmalia, 
Jurnal Kelautan, 14(1), 30-42 (2021)

N. R. (2017). The effectivity of ciprofloxacin on The growth of uropatogenic Escherichia Coli in Vitro. Jurnal Kedokteran Muhammadiya, 2, 17.

Masadeh, M. M., Alzoubi, K. H., Khabour, O. F., \& Al-azzam, S. I. (2014). Ciprofloxacin-induced antibacterial activity is attenuated by phosphodiesterase inhibitors. Current Therapeutic Research, 77, 14-17.

Melannisa, R., Da'i, M., \& Rahmi, R. T. (2011). Radical scavenging activity assay and determination of total phenolic content of ethanol extract three curcuma genus rhizomes and figerroot rhizome (Boesenbergia pandurata). Pharmacon, 12(1), 40-43.

Molyneux, P. (2004). The use of the stable free radical diphenylpicryl- hydrazyl (DPPH) for estimating antioxidant activity. Songklanakarin Journal of Science and Technology, 26, 211-219.

Moskovitz, J., Yim, M. Bin, \& Chock, P. B. (2002). Free radicals and disease. Archives of Biochemistry and Biophysics, 397(2), 354-359.

Mudgal, S., De Toni, A., Lockwood, S., Salès, K., Backhaus, T., \& Sorensen, B. H. (2013). Study on the environmental risks of medicinal products.

Mughal, M. S. N., Asghar, M. T., Zia, M. A., \& Ismail, T. (2009). Comparison of the antibacterial activities of different brands of Ciprofloxacin. Revista UDO Agrícola, 9(3), 700-704.

Naharuddin. (2020). Struktur dan Asosiasi Vegetasi Mangrove di Hilir DAS Torue, Parigi Moutong, Sulawesi Tengah. Jurnal Sylva Lestari, 8(3), 378-389.

Noor, Y. R., Khazali, M., \& Suryadiputra, I. N. . (2006). Panduan pengenalam mangrove di Indonesia (Kedua). Wetlands International Indonesia Programme.

Nurdiani, R., Firdaus, M., \& Prihanto, A. A. (2012). Phytochemical screening and antibacterial activity of methanol extract of mangrove plant (Rhyzophora mucronata) from Porong River Estuary. Journal Basic Science and Technology, 1(2), 27-29.

Nurjanah, N., Jacoeb, A. M., Hidayat, T., \& Shylina, A. (2015). Bioactive compounds and antioxidant activity of lindur stem bark (Bruguiera gymnorrhiza). International Journal of Plant Research, 1(5), 182-189.

Parekh, J., \& Chanda, S. (2007). Antibacterial and phytochemical studies on twelve species of Indian medicinal plants.
African Journal of Biomedical Research, 10(May), 175-181.

Paudel, B., Bhattarai, H. D., Kim, I. C., Lee, H., Sofronov, R., Ivanova, L., Poryadina, L., \& Yim, J. H. (2014). Estimation of antioxidant, antimicrobial activity and brine shrimp toxicity of plants collected from Oymyakon region of the republic of Sakha (Yakutia), Russia. Biological Research, 47(1), 1-6.

Pham-Huy, L. A., He, H., \& Pham-Huy, C. (2008). Free Radicals, Antioxidants in Disease and Health Lien. International Journal of Biomedical Science, 4(2), 8996.

Prabhu, V. V., \& Guruvayoorappan, C. (2012). Phytochemical screening of methanolic extract of mangrove Avicennia marina (Forssk.) Vierh. Pelagia Research Library Des Phamacia Sinica, 3(1), 64-70.

Prihantini, A. I., Krisnawati, Rahayu, A. A. D., Nugraheni, Y. M. M. A., \& Samawandana, G. (2018). Uji fitokimia dan aktivitas antibakteri tumbuhan pranajiwa (Euchresta horsfieldii (Lesch.) Benn.). Jurnal IImu Kehutanan, 12, 223233.

Putra, M. Y., Murniasih, T., Swasono, R. T., Wibowo, J. T., Saputri, A. N. C., Widhiana, M. R., \& Arlyza, I. S. (2016). Secondary metabolites and their biological activities in Indonesian soft coral of the genus Lobophytum. Asian Pacific Journal of Tropical Biomedicine, 6(11), 909-913.

Ramalingam, V., \& Rajaram, R. (2018). Enhanced antimicrobial, antioxidant and anticancer activity of Rhizophora apiculata: An experimental report. 3 Biotech, 8(4), 1-13.

Ravikumar, S., Gnanadesigan, M., Suganthi, P., \& Ramalakshmi, A. (2010). Antibacterial potential of chosen mangrove plants against isolated urinary tract infectious bacterial pathogens. International Journal of Medicine and Medical Sciences, 2(3), 94-99.

Revathi, P., Jeyaseelan Senthinath, T., Thirumalaikolundusubramanian, P., \& Prabhu, N. (2014). An overview of antidiabetic profile of mangrove plants. International Journal of Pharmacy and Pharmaceutical Sciences, 6(3), 1-5.

Ridlo, A., Supriyantini, E., \& Sedjati, S. (2019). Kandungan total fenolat pada ekstrak Rhizophora sp dari Teluk Awur, Jepara. Jurnal Kelautan Tropis, 22(1), 27-34.

Richter, A., Thonke, B., \& Popp, M. (1990). 1d1-O-methyl-muco-inositol in Viscum album and members of the 
Dewanto et al.,Profil GC-MS dari Ekstrak Daun Rizophora

Rhizophoraceae. Phytochemistry, 29(6), 1785-1786.

Rohman, A., Riyanto, S., \& Hidayat, N. K. (2007). Antioxidant activity, total phenolics and total flavonoid contents of Mengkudu (Morinda citrifolia L) Leaves. Agritech, 27(4), 147-151.

Sahoo, G., Mulla, N. S. S., Ansari, Z. A., \& Mohandass, C. (2012). Antibacterial activity of mangrove leaf extracts against human pathogens. Indian Journal of Pharmaceutical Sciences, 74(4), 348351.

Sivakumar, T. (2019). Phytochemical screening and gas chromatographymass spectroscopy analysis of bioactive compounds and biosynthesis of silver nanoparticles using sprout extracts of Vigna radiata I. And their antioxidant and antibacterial activity. Asian Journal of Pharmaceutical and Clinical Research, 12(2), 180-184.

Stover, C. K., Pham, X. Q., Erwin, A. L., Mizoguchi, S. D., Warrener, P., Hickey, M. J., Brinkman, F. S. L., Hufnagle, W. O., Kowalik, D. J., Lagrou, M., Garber, R. L., Goltry, L., Tolentino, E., Yuan, Y., Brody, L. L., Coulter, S. N., Folger, K. R., Kas, A., Larbig, K., ... Olson, M. V. (2000). Complete genome sequence of Pseudomonas aeruginosa PAO1, an opportunistic pathogen. Nature, 406(August), 959-964.

Sulistyaningsih, L., Koendhori, E. B., \& Ramadhani. (2012). Benzalkonium chloride and pine oil-containing cleaning fluid is not effective against Pseudomonas aeruginosa. Folia Medica Indonesiana, 48(3), 121-125.

Sumardi, Basyuni, M., \& Wati, R. (2018). Antimicrobial activity of polyisoprenoids of sixteen mangrove species from North Sumatra, Indonesia. Biodiversitas, 19(4), 1243-1248.

Sunita, A., \& Manju, S. (2017). Phytochemical examination and GC-MS analysis of methanol and ethyl- acetate extract of root and stem of Gisekia pharnaceoides Linn. (Molluginaceae) from Thar Desert, Rajasthan, India. Research Journal of Pharmaceutical , Biological and Chemical Sciences, 8(4), 168-174.

Tanod, W. A., Aristawati, A. T., Putra, M. Y., \& Muliadin. (2018). Soft coral (Sinularia sp.) extracts with antibacterial activity. Omni-Akuatika, 14(1), 108-117.

Tarman, K., Purwaningsih, S., \& Negara, A. A. A. P. P. (2013). Aktivitas antibakteri ekstrak daun bakau hitam (Rhizopora mucronata) terhadap bakteri penyebab diare. Jurnal Pengolahan Hasil

Perikanan Indonesia, 16(3), 249-258.

Thatoi, H. N., Patra, J. K., \& Das, S. K. (2014). Free radical scavenging and antioxidant potential of mangrove plants: A review. Acta Physiologiae Plantarum, 36(3), 561-579.

Tillah, M., Batubara, I., \& Sari, R. K. (2017). Antimicrobial and Antioxidant Activities of Resins and Essential Oil From Pine (Pinus merkusi, Pinuso ocarpa, Pinus insularis) and Agathis (Agathis loranthifolia). Biosaintifika: Journal of Biology \& Biology Education, 9(1), 134139.

Usman, Muh Amir, M., Erika, F., Nurdin, M., \& Kuncoro, H. (2019). Antidiabetic activity of leaf extract from three types of mangrove originating from Sambera coastal region Indonesia. Research Journal of Pharmacy and Technology, 12(4), 1707-1712.

Venkata, R. B., Samuel, L., Pardha, S. M., Narashimha, R. B., Naga, V. K. A., Sudhakar, M., \& Radhakrishnan, T. (2012). Antibacterial, antioxidant activity and GC-MS analysis of Eupatorium odoratum. Asian Journal of Pharmaceutical and Clinical Research, 5(Suppl 2), 99-106.

Wahyuni, W. T., Darusman, L. K., \& Surya, N. K. (2015). Potency of Rhizophora spp. extracts as antioxidants and inhibitor of acetylcholinesterase. Procedia Chemistry in International Symposium on Applied Chemistry, 16, 681-686.

WHO, World Health Organization. (2014). Antimicrobial resistance. In Bulletin of the World Health Organization (Vol. 61, Issue 3).

Yassa, N., Masoomi, F., Rankouhi, S. R., \& Hadjiakhoondi, A. (2009). Chemical composition and antioxidant activity of the extract and essential oil of Rosa damascena from Iran, population of Guilan. DARU Journal of Pharmaceutical Sciences, 17(3), 175-180.

Zhang, Z., Chen, M., Yu, Y., Pan, S., \& Liu, Y. (2018). Antimicrobial susceptibility among Gram-positive and Gramnegative blood-borne pathogens collected between 2012-2016 as part of the Tigecycline Evaluation and Surveillance Trial. Antimicrobial Resistance and Infection Control, 7(152), 1-13. 